\title{
Frequency of species of Eimeria in females of the holstein-friesian breed at the post-weaning stage during autumn and winter
}

Frequência das espécies de Eimeria em fêmeas da raça holandesa na fase de recria durante o outono-inverno

Fábio Raphael Pascoti Bruhn ${ }^{1 *}$; Marcos Aurélio Lopes ${ }^{1}$; Fabiana Alves Demeu ${ }^{1}$; Caio Augusto Perazza ${ }^{1}$; Marcos Ferrazani Pedrosa ${ }^{1}$; Antônio Marcos Guimarães ${ }^{1}$

${ }^{1}$ Departamento de Medicina Veterinária, Universidade Federal de Lavras - UFLA

Received February 25, 2011

Accepted April 26, 2011

\begin{abstract}
The frequency of species of the genus Eimeria in a dairy herd in the municipality of Boa Esperança, Southern region of the State of Minas Gerais was assessed. From 37 females of the Friesian breed aged three to seven months, 259 feces samples were analyzed between May and September 2008. The examinations to quantify oocysts per gram of feces (OPG) and identify Eimeria species were conducted at the Veterinary Parasitology Laboratory of the Federal University of Lavras. Eleven species of Eimeria were identified, namely: E. bovis (23.2\%), E. zuernii (22.6\%), E. ellipsoidalis (20.3\%), E. cylindrica (14.1\%), E. subspherica (5.4\%), E. canadensis (3.5\%), E. alabamensis (2.4\%), E. auburnensis (2.4\%), E. pellita (2.1\%), E. brasiliensis (2\%) and E. bukidnonensis (1.9\%). E. bovis, E. zuernii and E. ellipsoidalis were the most frequent and the ones with the highest oocyst shedding over time $(\mathrm{p}<0.05)$. Differences in OPG counts were found between most months studied ( $\mathrm{p}<0.05$ ). The large number of Eimeria species found, in particular E. bovis and E. zuernii, indicates that Eimeria sp. has significant pathogenic potential in dairy cattle in the South of Minas Gerais.
\end{abstract}

Keywords: Eimeria sp., dairy cattle, frequency.

\section{Resumo}

Avaliou-se a frequência das espécies do gênero Eimeria em um rebanho leiteiro, criado no município de Boa Esperança, região Sul do Estado de Minas Gerais. Foram analisadas 259 amostras de fezes de 37 fêmeas bovinas, da raça holandesa, com faixa etária compreendida entre três e sete meses, no período de maio a setembro de 2008. O exame para quantificar oocisto por grama de fezes (OPG) e identificação das espécies de Eimeria foi realizado no Laboratório de Parasitologia Veterinária da UFLA. Foram identificadas onze espécies de Eimeria, sendo elas: E. bovis (23,2\%), E. zuernii (22,6\%), E. ellipsoidalis (20,3\%), E. cylindrica (14,1\%), E. subspherica (5,4\%), E. canadensis (3,5\%), E. alabamensis (2,4\%), E. auburnensis (2,4\%), E. pellita (2,1\%), E. brasiliensis (2\%) e E. bukidnonensis, sendo E. bovis, E. zuernii e E. ellipsoidalis as mais frequentes e aquelas com maior número de oocistos eliminados ao longo do tempo $(\mathrm{p}<0,05)$. Diferenças na contagem de OPG foram encontradas na maioria dos meses avaliados $(\mathrm{p}<0,05)$. A grande quantidade de espécies de Eimeria encontradas, em especial E. bovis e E. zuernii, indicam um importante potencial patogênico da Eimeria sp. em gado leiteiro no Sul de Minas Gerais.

Palavras-chave: Eimeria sp., bovinos leiteiros, frequência.

\section{Introduction}

Eimeriosis is a disease caused by coccid protozoa belonging to the phylum Apicomplexa, family Eimeriidae and genus Eimeria that parasitize poultry, ruminants, equines and rabbits. These parasites have worldwide distribution and especially affect dairy cattle under one year of age.

\footnotetext{
*Corresponding author: Fábio Raphael Pascoti Bruhn

Departamento de Medicina Veterinária, Universidade Federal de Lavras - UFLA, CP 3037, CEP 37200-000, Lavras, MG, Brasil

e-mail: fabio_rpb@yahoo.com.br
}

This disease is one of the main causes of economic losses in rearing ruminants worldwide. Matjila and Penzhorn (2002) estimated that the losses were US\$ 400 million/year in cattle-rearing in the United States, without taking into account losses caused by subclinical coccidiosis.

Under conditions of intensive rearing, as practiced in a large proportion of dairy cattle farms, with high population density, disease transmission takes place more readily and oocysts are highly available within the environment. Thus, in dairy calves, eimeriosis occurs more frequently and appears with greater severity (LIMA, 2004). 
Stressful situations such as weaning, transportation, starting of confinement, changes in the weather and debility caused by other pathogens may induce outbreaks of eimeriosis (SÁNCHEZ et al., 2008; REHMAN et al., 2010). Thirteen species of Eimeria have been cited as causing production and economic losses to cattle producers around the world, and E. zuernii and E. bovis are considered to be the most pathogenic species (CORNELISSEN et al., 1995; LIMA, 2004; TAUBERT et al., 2008). These two species cause severe diarrhea with feces containing blood, fibrin and intestinal tissue, as well as fever, pain, tenesmus, anemia, dehydration, weakness, anorexia and weight loss. These conditions may lead to the death of the host (DAUGSCHIES; NAJDROWSKI, 2005; TAUBERT et al., 2008).

Studies have demonstrated that the prevalence of Eimeria species in cattle varies between different regions of Brazil (REBOUÇAS et al., 1994; ALMEIDA et al., 2011). Given that there are differences in pathogenicity between species (LIMA, 2004), the impact of eimeriosis may also vary between regions. This indicates the importance of knowledge of the frequency of occurrence of each species in herds, especially in the South of the State of Minas Gerais, which is one of the biggest milk-producing areas in Brazil.

Health and management within cattle-rearing are critical points of great importance and thus should be controlled in order to make this activity viable. The present study had the aim of investigating the frequencies of occurrence of species of the genus Eimeria in female calves at the post-weaning stage, in a dairy herd located in the Southern region of the State of Minas Gerais, during the Southern hemisphere autumn and winter.

\section{Material and Methods}

This study was conducted in a milk production system located in the municipality of Boa Esperança, in the Southern region of the State of Minas Gerais ( $21^{\circ} 05^{\prime} 24^{\prime \prime} \mathrm{S}$ and $\left.45^{\circ} 33^{\prime} 57^{\prime \prime} \mathrm{W}\right)$.

The animals had previously been identified by means of conventional tags in both ears and an electronic tag in the left ear (containing a specific number on a microchip). They were kept continuously in three fenced-in grassed paddocks (grass type Cynodon sp.), at a mean stocking density of $100 \mathrm{~m}^{2}$.animal ${ }^{-1}$. They had access ad libitum to maize silage and received Purina Milktech 45 concentrate $\left(2 \mathrm{~kg} \cdot\right.$.animal ${ }^{-1} /$ day $)$, and this management regimen was maintained throughout the period evaluated.

From 37 females of the Friesian breed aged three to seven months, 259 feces samples were analyzed between May and September 2008. The situation evaluated in this study was in line with the normal management followed at this farm property, since the young animals were kept together in paddocks separated from the cows that were already of reproductive age. The samples were collected directly from the rectal ampulla with the aid of plastic bags, every 30 days, with the exception of the months of June and September, when two collections with a 15-day interval between them were made. The feces samples in the plastic bags were identified with the animal's number and were stored at a temperature of $4^{\circ} \mathrm{C}$, for subsequent laboratory evaluation.

The examinations to quantify oocysts per gram of feces (OPG) and identify Eimeria species were conducted at the Veterinary
Parasitology Laboratory of the Federal University of Lavras, using the method of Gordon and Whitlock (1939), as modified by Ueno and Gonçalves (1998), in a McMaster chamber. The positive samples were left to sporulate in Petri dishes with $2.5 \%$ potassium dichromate solution for seven days, in a germination chamber at a temperature of $28^{\circ} \mathrm{C}$, for subsequent identification of Eimeria species. After the sporulation process, the samples were centrifuged for 10 minutes at a rotation of $595.1 \mathrm{~g}$, and were then placed between a slide and cover slip and observed under a microscope at magnifications of up to 400X (HOFFMAN, 1987). The species were differentiated from each other in terms of the oocyst characteristics of shape, color, size and presence or absence of micropyles and micropylar hoods, along with the morphological characteristics of the sporocysts, in accordance with the parameters of Amarante and Barbosa (1992).

The Shapiro-Wilk normality test was applied to the variables of percentage occurrence of Eimeria species and OPG count among the species found during the months evaluated. This showed that the data presented asymmetrical distribution and, for this reason, the nonparametric Kruskal-Wallis test was then used on these two variables. In the event of statistical significance ( $p<0.05$ ), the Mann-Whitney test was used between the species. The nonparametric Friedman test for paired samples was also performed for the months with OPG counts, and the Wilcoxon test was then performed between the months, in cases of statistical significance. The descriptive and inductive analyses were performed using the Excel application and the SPSS 17.0 statistical software. The results were grouped in the form of tables and graphs, with the aim of enabling better comparison, discussion and presentation of the results (LOPES et al., 2004).

\section{Results and Discussion}

Differences in the occurrences of different species of Eimeria were observed over the course of the months evaluated $(\mathrm{p}<0.05)$. In this study, 11 Eimeria were identified (Table 1), which was more than was found in the investigations by Rebouças et al. (1994) in São Paulo and by Almeida et al. (2011) in Bahia, who did not find E. pellita. Rebouças et al. (1994) also found E. wyomingensis, but did not find E. auburnensis.

The frequency of occurrence of E. zuernii in the present study was $22.6 \%$, which was well above the 9.7 and $6.83 \%$ found, respectively, by Rebouças et al. (1994) and Almeida et al. (2011). On the other hand, for E. bovis, the frequency found (23.2\%) was very similar to the findings in the other two studies. These results indicate that in Brazil, E. bovis is one of the most important species, given that it has repeatedly been found to be the most frequent species in Brazil (REBOUÇAS et al., 1994; LASSEN et al., 2009a; REHMAN et al., 2010).

In Argentina, Sánchez et al. (2008) found that 12 Eimeria species were present in calves, among which E. ellipsoidalis (38\%) was the most frequent, followed by E. bovis (24\%), E. auburnensis (19\%), E. zuernii (11\%), E. canadensis (4\%) and E. subspherica (3\%), and in smaller percentages, E. alabamensis, E. wyomingensis, E. cylindrica, E. bukidnonensis, E. brasiliensis and E. illinoisensis. In Germany, a smaller number of species of Eimeria was found to be 
Table 1. Species of the genus Eimeria identified in the feces of female Friesian calves between May and September 2008, in the State of Minas Gerais.

\begin{tabular}{|c|c|c|c|c|c|c|c|c|c|c|c|c|}
\hline \multirow{2}{*}{$\begin{array}{c}\text { Eimeria } \\
\text { species }\end{array}$} & \multicolumn{2}{|c|}{ May } & \multicolumn{2}{|c|}{ June } & \multicolumn{2}{|c|}{ July } & \multicolumn{2}{|c|}{ August } & \multicolumn{2}{|c|}{ September } & \multicolumn{2}{|c|}{ Mean* } \\
\hline & $\%$ & OPG & $\%$ & OPG & $\%$ & OPG & $\%$ & OPG & $\%$ & OPG & $\%$ & OPG \\
\hline E. zuernii & 25.2 & 59.7 & 22.2 & 414.0 & 21 & 36.7 & 19.8 & 41.1 & 24.8 & 61.3 & $22.6^{\mathrm{a}}$ & $123.5^{\mathrm{a}}$ \\
\hline E. bovis & 23.4 & 55.5 & 22.6 & 421.5 & 22.8 & 39.8 & 25 & 51.9 & 22 & 54.4 & $23.2^{\mathrm{a} \cdot \mathrm{b}}$ & $126.7^{a}$ \\
\hline E. ellipsoidalis & 19 & 45 & 19.4 & 361.8 & 19.2 & 33.5 & 22.8 & 47.4 & 21 & 51.9 & $20.3^{\mathrm{b}}$ & $110.9^{a}$ \\
\hline E. cylindrica & 14.2 & 33.7 & 14.4 & 268.6 & 14.4 & 25.1 & 13.8 & 28.7 & 13.6 & 33.6 & $14.1^{c}$ & $77.0^{\mathrm{a} . \mathrm{b}}$ \\
\hline E. subspherica & 4.8 & 11.4 & 6.6 & 123.1 & 6.2 & 10.8 & 4.6 & 9.6 & 4.8 & 11.9 & $5.4^{\mathrm{d}}$ & $29.5^{\mathrm{a} \cdot \mathrm{c}}$ \\
\hline E. canadensis & 3.6 & 8.5 & 4.2 & 78.3 & 4.2 & 7.3 & 2.8 & 5.8 & 2.6 & 6.4 & $3.5^{\mathrm{e}}$ & $19.1^{\mathrm{a} \cdot \mathrm{c}}$ \\
\hline E. alabamensis & 2.6 & 6.2 & 2.4 & 44.8 & 2.2 & 3.8 & 2.4 & 5.0 & 2.6 & 6.4 & $2.4^{\mathrm{f}}$ & $13.1^{\mathrm{c}}$ \\
\hline E. auburnensis & 2.4 & 5.7 & 2.2 & 41.0 & 2.2 & 3.8 & 2.6 & 5.4 & 2.4 & 5.9 & $2.4^{\mathrm{fg}}$ & $13.1^{\mathrm{b} . c}$ \\
\hline E. pellita & 2 & 4.7 & 1.6 & 29.8 & 1.6 & 2.8 & 2.4 & 5.0 & 2.8 & 6.9 & $2.1^{\text {f.g.h }}$ & $11.5^{\mathrm{c}}$ \\
\hline E. bukidnonensis & 1.5 & 3.6 & 2.2 & 41.0 & 2.4 & 4.2 & 2.2 & 4.6 & 1.4 & 3.5 & $1.9^{\mathrm{g} \cdot \mathrm{h}}$ & $10.4^{b \cdot c}$ \\
\hline E. brasiliensis & 2.2 & 5.2 & 2.2 & 41.0 & 2.2 & 3.8 & 1.6 & 3.3 & 2 & 4.9 & $2^{\text {e.h }}$ & $10.9^{\mathrm{b} . c}$ \\
\hline Mean ${ }^{* *}$ & - & $21.7^{\mathrm{a} \cdot \mathrm{d}}$ & - & $169.6^{\mathrm{b}}$ & - & $15.6^{c}$ & - & $18.9^{\mathrm{a}}$ & - & $22.5^{\mathrm{d}}$ & - & - \\
\hline Total & - & 239.2 & - & 1864.9 & - & 171.6 & - & 207.8 & - & 247.1 & - & 545.7 \\
\hline
\end{tabular}

"Means followed by different letters in the same column differ statistically $(\mathrm{p}<0.05)$ according to the Mann-Whitney test. "Means followed by different letters in the same line differ statistically $(\mathrm{p}<0.05)$ according to the Wilcoxon test.

parasitizing grazing calves, among which E. alabamensis was the most prevalent species (83.3\%), followed by E. bovis $(58.9 \%)$ and E. zuernii (3.1\%) (SAMSON-HIMMELSTJERNA et al., 2006). In the Netherlands, Cornelissen et al. (1995) found that eight species of Eimeria were present in heifers, among which $E$. bovis (34.3\%) and E. auburnensis (18.9\%) were the most frequent; and 12 species in calves, among which E. bovis (27.8\%) was again the most frequent species, followed by E. ellipsoidalis $(22.5 \%)$.

In the present study, E. bovis and E. zuernii were seen to be the most frequent species. These are the most pathogenic species, since they mainly affect young animals (TAUBERT et al., 2008). These are the species most commonly associated with the clinical conditions characteristic of eimeriosis (CORNELISSEN et al., 1995). The third most frequent species in our study was E. ellipsoidalis. Thus, our data corroborate the report by Parker and Jones (1987), who found that oocysts of E. bovis, E. ellipsoidalis and E. zuernii were the types most commonly shed by cattle up to the age of eight months that were reared on pasture, i.e. under conditions similar to those of the present study.

The mean number of oocysts released varied according to the month and species $(\mathrm{p}<0.05)$ (Table 1). Differences were found between all the months evaluated, except between the counts for May and August and between the counts for May and September. The species E. bovis, E. zuernii, E. ellipsoidalis, E. cylindrica, E. subspherica and E. canadensis were the ones that presented the greatest oocyst shedding (Table 1). However, in the present study, infection due to Eimeria occurred at a subclinical level, i.e. it was not possible to diagnose clinical cases of eimeriosis, or to examine the viscera of suspected animals, or even to detect the evolutional stages of the parasite, as already seen by Cornelissen et al. (1995) and Almeida et al. (2011), also among dairy cattle.

On the other hand, Samson-Himmelstjerna et al. (2006) found that $80 \%$ of the calves that they evaluated in Germany presented clinical cases of the disease. This difference may have been caused by different doses of infecting oocysts and species present (JOLLEY;
BARDSLEY, 2006) among the studies. Moreover, management factors may also be related to greater susceptibility of cattle to this parasitosis, given that according to Sánchez et al. (2008), calves that are reared under artificial conditions are exposed to greater numbers of risk factors for eimeriosis, such as: early weaning, failure to ingest colostrum and difficulty in adapting to artificial high-density diets. According to the same authors, these factors impair the establishment of an adequate immune response, which would be the determining factor for resistance to coccidiosis. It is important to emphasize that, even in the subclinical form, the lesions caused by different species of this parasite may be related to lower nutrient absorption, with an effect on the performance, health and production of the animals (LASSEN et al., 2009a).

According to Jolley and Bardsley (2006), moderate temperatures favor development of the biological cycle of the parasite. Furthermore, Lassen et al. (2009b) found that cows shed greater quantities of oocysts under conditions of high humidity, and Rehman et al. (2010) found that in the rainy months, the prevalence of eimeriosis increased. In the present study, a lower OPG count was found in July ( $<<0.05)$, which is the start of the dry period of the year. Thus, knowledge of the conditions that favor parasite development is important for establishing control strategies, both in the rainy season and in the dry season, given that infection can even occur during the latter period. This is even more important when it is borne in mind that different species present different pathogenesis (JOLLEY; BARDSLEY, 2006), and that their occurrence may vary over the seasons of the year.

The month of June was differentiated from the other months in relation to the OPG count (Table 1), such that the highest peak of oocyst shedding was found in this month (Figure 1). The cause of this difference may have been an incident in which cows at the peripartum stage accidentally gained access to the paddock where the calves were. Faber et al. (2002) suggested that close to the time of calving, the OPG count in feces increases, which may result in contamination of the pasture. Michel et al. (1972), in England, 


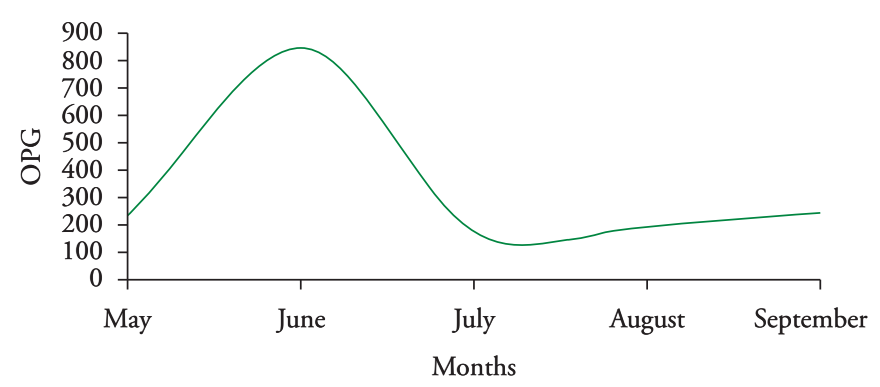

Figure 1. Mean number of oocysts per gram of feces (OPG) found in the feces of female Friesian calves during the Southern hemisphere autumn and winter of 2008, in the State of Minas Gerais.

reported that oocyst production in naturally infected cows increased during the peripartum period, with greater contamination of pasture during this period. Lassen et al. (2009b) also found that calves that were reared separately from adult animals presented lower oocyst shedding. This occurs because adult animals act as reservoirs for the agent and sources of infection for young animals, given that although immunity to Eimeria is species-specific, it is not absolute (JOLLEY; BARDSLEY, 2006; LIMA, 2004). This makes it necessary to take care at the time of dividing the animals according to category.

Also in June, it was observed that there were greater numbers of animals per unit area in the paddock. Pasture with high concentrations of animals also present greater quantities of feces deposited, and consequently, greater contamination of the ground with parasite eggs and oocysts, which constitutes a risk for susceptible calves (JOLLEY; BARDSLEY, 2006). Sánchez et al. (2008) found that greater prevalences occurred when the calves were subjected to higher rearing densities. They noted that the parasitic infection rate increased because of the high animal burden per unit of surface area and estimated that the infection rate became four times higher when the population density doubled (SÁNCHEZ et al., 2008).

The sampling done in June took place 30 days after the animals had been brought into the paddock. This length of time is more than the duration of the prepatent period of Eimeria species, which may explain the increase observed in this month. However, in the following month, a considerable decrease in OPG count was observed. This fall was probably related to host immunity action against Eimeria, which already exists in calves aged three to seven months, like those in the present study (FABER et al., 2002). The decrease in the animal density in the paddock in July, in relation to June, and the less favorable environmental conditions for sporulation of oocysts, such as the low humidity at this time of the year, may also be related to the observed decline in OPG count, thus causing the observed differences between the months $(\mathrm{p}<0.05)$.

\section{Conclusion}

The influence of the management implemented at the farm property, on oocyst shedding, and the large number of Eimeria species encountered, particularly E. bovis and E. zuernii, indicate that Eimeria has significant pathogenic potential and that there is a need to control it among dairy cattle in the South of the State of Minas Gerais.

\section{Acknowledgements}

The authors thank FAPEMIG (Fundação de Amparo à Pesquisa do Estado de Minas Gerais; Research Support Foundation of the State of Minas Gerais) for the support received for conducting this study.

\section{References}

ALMEIDA, V. A. et al. Frequency of species of the Genus Eimeria in naturally infected cattle in Southern Bahia, Northeast Brazil. Revista Brasileira de Parasitologia Veterinária, v. 20, n. 1, p. 78-81, 2011.

AMARANTE, A. F. T.; BARBOSA, M. A. Species of coccidia occurring in lambs in São Paulo State, Brazil. Veterinary Parasitology, v. 41, n. 3-4, p.189-193, 1992. http://dx.doi.org/10.1016/0304-4017(92)90078-N

CORNELISSEN, A. W. C. A. et al. An observational study of Eimeria species in housed cattle on Dutch dairy farms. Veterinary Parasitology, v. 56, n. 1-3, p. 7-16, 1995. http://dx.doi.org/10.1016/03044017(94)00671-X

DAUGSCHIES, A.; NAJDROWSKI, M. Eimeriosis in Cattle: Current Understanding. Journal of Veterinary Medicine, v. 52, n. 10, p. 417-427, 2005. PMid:16364016. http://dx.doi.org/10.1111/j.14390450.2005.00894.x

FABER, J. E. et al. Eimeria infections in cows in the periparturient phase and their calves: oocyst excretion and levels of specific serum and colostrum antibodies.Veterinary Parasitology, v. 104, n. 1, p. 1-17, 2002. http://dx.doi.org/10.1016/S0304-4017(01)00610-0

GORDON, H. M.; WHITLOCK, H. V. A new technique for counting nematode eggs in sheep faeces. Council for Scientific and Industrial Research Austrália, v. 12, n. 1, p. 50-52, 1939.

HOFFMAN, R. P. Diagnóstico de parasitismo veterinário. Porto Alegre: Sulina, 1987. $156 \mathrm{p}$.

JOLLEY, W. R.; BARDSLEY, K. D. Ruminant Coccidiosis. Veterinary Clinics Food Animal, v. 22, n. 3, p. 613-621, 2006. PMid:17071356. http://dx.doi.org/10.1016/j.cvfa.2006.07.004

LASSEN, B. et al. Eimeria and Cryptosporidium in Estonian dairy farms in regard to age, species, and diarrhoea. Veterinary Parasitology, v. 166, n. 3-4, p. 212-219, 2009a. PMid:19747778. http://dx.doi.org/10.1016/j. vetpar.2009.08.022

LASSEN, B.; VILTROP, A.; JÄRVIS, T. Herd factors influencing oocyst production of Eimeria and Cryptosporidium in Estonian dairy cattle. Parasitology Research, v. 105, n. 5, p. 1211-1222, 2009 b. PMid:19557434. http://dx.doi.org/10.1007/s00436-009-1540-8

LIMA, J. D. Coccidiose dos ruminantes domésticos. Revista Brasileira de Parasitologia Veterinária, v. 13, supl. 1, p. 9-13, 2004.

LOPES, M. A. et al. Efeito do tipo de sistema de criação nos resultados econômicos de sistemas de produção de leite na regiáo de Lavras (MG). Ciência e Agrotecnologia, v. 28, n. 5, p.1177-1189. 2004.

MATJILA, P. T.; PENZHORN, B. L. Occurrence and diversity of bovine coccidia at three localities in South Africa. Veterinary Parasitology, 
v. 104, n. 2, p. 93-102, 2002. http://dx.doi.org/10.1016/S03044017(01)00605-7

MICHEL, J. F.; LANCASTER, M. B.; HONG, C. The epidemiology of gastro-intestinal nematode infection in the single-suckled calf. The Veterinary Record, v. 91, n. 13, p. 301-306, 1972. PMid:5086409. http://dx.doi.org/10.1136/vr.91.13.301

PARKER, R. J.; JONES, G. W. The development of Eimerian infections during the first eight months of life in unweaned beef calves in a dry tropical region of Australia. Veterinary Parasitology, v. 25, n. 1, p. 1-7, 1987. http://dx.doi.org/10.1016/0304-4017(87)90059-8

REBOUÇAS, M. M. et al. Prevalência e distribuição de protozoários do gênero Eimeria (Apicomplexa: Eimeriidae) em bovinos nos municípios de Altinópolis, Taquaritinga, São Carlos e Guairá - Estado de São Paulo, Brasil. Revista Brasileira de Parasitologia Veterinária, v. 3, n. 2, p. 125-130, 1994.

REHMAN, T. U. et al. Epidemiology of Eimeria and associated risk factors in cattle of district Toba Tek Singh, Pakistan. Parasitology Research, v. 108, n. 5, p. 1171-1177, 2010. PMid:21110042. http://dx.doi.org/10.1007/s00436-010-2159-5
SAMSON-HIMMELSTJERNA, G. V. et al. Clinical and epidemiological characteristics of Eimeria infections in first-year grazing cattle. Veterinary Parasitology, v. 136, n. 3-4, p. 215-221, 2006. PMid:16387444. http://dx.doi.org/10.1016/j.vetpar.2005.11.022

SÁNCHEZ, R. O.; ROMERO, J.R.; FOUNROGE, R.D. Dynamics of Eimeria oocyst excretion in dairy calves in the Province of Buenos Aires (Argentina), during their first 2 months of age. Veterinary Parasitology, v. 151, n. 2-4, p. 133-138, 2008. PMid:18096320. http://dx.doi. org/10.1016/j.vetpar.2007.11.003

TAUBERT, A. et al. Antigen-induced cytokine production in lymphocytes of Eimeria bovis primary and challenge infected calves. Veterinary Immunology and Immunopathology, v. 126, n. 3-4, p. 309-320, 2008. PMid:18947883. http://dx.doi.org/10.1016/j. vetimm.2008.09.003

UENO, H.; GONÇALVES, P. C. Manual para diagnóstico das helmintoses de ruminantes. 4. ed. Tokio: Japan International Cooperation Agency, 1998. p. 14-15, 25-28. 